\title{
4-Acetylantroquinonol B Inhibits Osteoclastogenesis by Inhibiting the Autophagy Pathway in a Simulated Microgravity Model
}

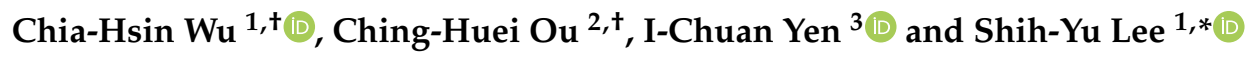 \\ 1 Graduate Institute of Aerospace and Undersea Medicine, National Defense Medical Center, Taipei 11490, \\ Taiwan; chiahsin.ch.wu@gmail.com \\ 2 Department of Anesthesiology, Cheng-Hsin General Hospital, Taipei 11220, Taiwan; 0940209@yahoo.com.tw \\ 3 School of Pharmacy, National Defense Medical Center, Taipei 11490, Taiwan; \\ yenichuan@mail.ndmctsgh.edu.tw \\ * Correspondence: leeshihyuno1@mail.ndmctsgh.edu.tw; Tel.: +886-2-87923100; Fax: +886-2-87927380 \\ + These authors contributed equally to this work.
}

Received: 26 August 2020; Accepted: 18 September 2020; Published: 22 September 2020

\begin{abstract}
Astronauts suffer from 1-2\% bone loss per month during space missions. Targeting osteoclast differentiation has been regarded as a promising strategy to prevent osteoporosis in microgravity $(\mu \mathrm{Xg})$. 4-acetylantroquinonol B (4-AAQB), a ubiquinone from Antrodia cinnamomea, has shown anti-inflammatory and anti-hepatoma activities. However, the effect of 4-AAQB on $\mu \mathrm{Xg}$-induced osteoclastogenesis remains unclear. In this study, we aimed to explore the mechanistic impact of 4-AAQB on osteoclast formation under $\mu \mathrm{Xg}$ conditions. The monocyte/macrophage-like cell line RAW264.7 was exposed to simulated $\mu \mathrm{Xg}$ (Rotary Cell Culture System; Synthecon, Houston, TX, USA) for $24 \mathrm{~h}$ and then treated with 4-AAQB or alendronate (ALN) and osteoclast differentiation factor receptor activator of nuclear factor kappa-B ligand (RANKL). Osteoclastogenesis, bone resorption activity, and osteoclast differentiation-related signaling pathways were analyzed using tartrate-resistant acid phosphatase (TRAP) staining, actin ring fluorescent staining, bone resorption, and western blotting assays. Based on the results of TRAP staining, actin ring staining, and bone resorption assays, we found that 4-AAQB significantly inhibited $\mu \mathrm{Xg}$-induced osteoclast differentiation. The critical regulators of osteoclast differentiation, including nuclear factor of activated T-cells cytoplasmic 1 (NFATc1), c-Fos, and dendritic cell-specific transmembrane protein (DC-STAMP), were consistently decreased. Meanwhile, osteoclast apoptosis and cell cycle arrest were also observed along with autophagy suppression. Interestingly, the autophagy inhibitors 3-methyladenine (3-MA) and chloroquine (CQ) showed similar effects to 4-AAQB. In conclusion, we suggest that 4-AAQB may serve as a potential agent against $\mu \mathrm{Xg}$-induced osteoclast formation.
\end{abstract}

Keywords: 4-acetylantroquinonol B; microgravity; osteoclastogenesis; autophagy

\section{Introduction}

In a space environment, several risk factors threaten the health of astronauts, including variations in gravity and radiation [1]. Astronauts face multiple challenges in a microgravity $(\mu \mathrm{Xg})$ environment, including deconditioning of the cardiovascular system, suppression of immune function, and imbalance of bone metabolism during spaceflights [2-6]. Among these, skeletal metabolism-related problems pose a ubiquitous concern among space travelers. One long-term study found that astronauts lose an average bone density of $11 \%$ over a $4-6$ month mission [2]. In general, astronauts experience decreases of $1 \%$ muscle mass and $1.8-2 \%$ bone density per month [3]. Although resistance exercises promote muscle mass maintenance, bone loss remains a problem for astronauts due to an imbalance between 
bone formation and bone resorption. Studies have reported that exposure to a $\mu \mathrm{Xg}$ environment results in decreased osteoblast formation [7] and increased osteoclast differentiation [8]. Therefore, targeting osteoclastogenesis has been regarded as a promising strategy to prevent osteoporosis in $\mu \mathrm{Xg}$ conditions $[8,9]$.

Osteoclasts originate from the monocyte-macrophage lineage, and many factors are involved in the process of osteoclast differentiation. c-Fos and nuclear factor of activated T-cells cytoplasmic 1 (NFATc1) are two important factors involved in osteoclast differentiation [10,11]. Dendritic cell-specific transmembrane protein (DC-STAMP) also participates in osteoclast differentiation and is related to cell-cell fusion [12,13]. Two inflammatory related pathways, nuclear factor kappa-light-chain-enhancer of activated B cells (NF- $\mathrm{B}$ ) and mitogen-activated protein kinases (MAPKs), regulate osteoclast differentiation and function [14]. At present, the methods to alleviate overactivated osteoclasts include inhibiting osteoclastogenesis, inducing cell apoptosis, and inhibiting osteoclast resorption activities [15]. Bisphosphonate, a current treatment for osteoporosis, inhibits osteoclast formation and function by activating the caspase- 3 and caspase- 9 apoptosis signaling pathways [16,17]. Autophagy is also involved in osteoclastogenesis. Overexpression of Beclin-1 has been observed to suppress osteoclast precursor apoptosis [18] while autophagy inhibitors consistently suppress osteoclastogenesis [19].

Current bone loss prevention methods during space missions involve exercise and drug intervention [20-22]; however, a more effective mechanism needs to be developed. 4-acetylantroquinonol B (4-AAQB), a ubiquinone from Antrodia cinnamomea, has been found to possess anti-inflammatory [23,24], antioxidant [25], and anti-hepatoma properties [24,26]. A recent study showed that 4-AAQB suppresses autophagic flux through the PI3K signaling pathway in epithelial cancer cells [27]. It is well known that the inflammatory and autophagy signaling pathways are highly associated with osteoclastogenesis [18,28]. These findings imply a role of 4-AAQB in osteoclastogenesis regulation. This study aimed to explore the mechanistic impact of 4-AAQB on osteoclast formation under $\mu \mathrm{Xg}$ conditions.

\section{Materials and Methods}

\section{1. $4-A A Q B$}

4-AAQB was prepared as previously described. Briefly, dried A. cinnamomea mycelium was extracted with $95 \%$ alcohol, and the extract was successively partitioned with dichloromethane and water. The dichloromethane-soluble fraction ( $60 \mathrm{~g}$ from $1305.3 \mathrm{~g}$ of mycelium) was subjected to column chromatography and high-performance liquid chromatography separation as described previously $[29,30]$.

\subsection{Cell Culture}

The RAW264.7 cell line was purchased from the American Type Culture Collection (Manassas, VA, USA). RAW264.7 cells are widely used for studying osteoclastogenesis [9,31,32]. The cells were maintained at $37^{\circ} \mathrm{C}$ in an atmosphere of $5 \% \mathrm{CO}_{2}$ in Dulbecco's Modified Eagle Medium supplemented with $10 \%$ fetal bovine serum. Receptor activator of nuclear factor- $\mathrm{kB}$ ligand (RANKL; $100 \mathrm{ng} / \mathrm{mL}$ ) was added to induce osteoclast differentiation.

\subsection{Cell Viability Assay}

Cell viability was determined using the alamarBlue Cell Viability assay kit (Invitrogen ${ }^{\mathrm{TM}}$, Thermo Fisher Scientific Inc., Waltham, MA, USA) as previously described [33]. Briefly, the cells $\left(1 \times 10^{4}\right.$ cells/well) were seeded into 96-well plates for $24 \mathrm{~h}$. After treatment with 4-AAQB or alendronate (ALN) for $72 \mathrm{~h}$, an alamarBlue solution was added for $2 \mathrm{~h}$ at $37^{\circ} \mathrm{C}$. The absorbance was measured at $570 / 630 \mathrm{~nm}$ using a spectrophotometer (Spectra Max 190; Molecular Devices, Sunnyvale, CA, USA). 


\subsection{Rotary Cell Culture System (RCCS)}

The RCCS (Synthecon, Houston, TX, USA) is a system that provides a low-shear $\mu$ Xg-like environment. The rotary speed of the RCCS was set at $12 \mathrm{rpm}$, and the cells were incubated in the RCCS for $24 \mathrm{~h}$ to simulate $\mu \mathrm{Xg}(0.004 \mathrm{Xg})$ or normal-gravity $(\mathrm{v}-\mathrm{Xg})$, which rotated around a vertical or horizontal axis [9].

\subsection{Tartrate-Resistant Acid Phosphatase (Trap) Staining}

The cells were fixed with fixation solution supplemented with $10 \%$ formaldehyde for $10 \mathrm{~min}$ at $25^{\circ} \mathrm{C}$ and then stained with TRAP solution (Sigma-Aldrich, St. Louis, MO, USA) for $20 \mathrm{~min}$ [34]. Images were visualized with a light microscope (DMi8; Leica Microsystems, Wetzlar, Germany). The number of TRAP $(+)$ cells/well and area of TRAP $(+)$ cells $(\%)$ were measured using ImageJ software version 1.50a (National Institutes of Health [NIH], Bethesda, MD, USA).

\subsection{Actin Ring Immunofluorescence}

The cells were fixed with $4 \%$ methanol-free formaldehyde for $10 \mathrm{~min}$ at $25^{\circ} \mathrm{C}$. Later, the cells were stained with Alexa Fluor ${ }^{\circledR} 488$ Phalloidin (Cell Signaling Technology, Danvers, MA, USA) in the dark for $15 \mathrm{~min}$ at $25^{\circ} \mathrm{C}$. Then, the cells were washed and stained with nuclear $4^{\prime}, 6$-diamidino-2-phenylindole dye (Cell Signaling Technology) in the dark for $5 \mathrm{~min}$ at $25^{\circ} \mathrm{C}$ [35]. Images were visualized with a light microscope (DMi8; Leica Microsystems). The number of actin rings/well was measured using ImageJ software version $1.50 \mathrm{a}(\mathrm{NIH})$.

\subsection{Osteo Assay}

After being cultured in Corning Osteo Assay (Corning, Inc., Corning, NY, USA) 96-well plates for $120 \mathrm{~h}$, the cells were incubated with the bleach solution for $5 \mathrm{~min}$ at room temperature. The plates were washed with distilled water twice and dried at room temperature for $5 \mathrm{~h}$ [36]. Images were visualized with a light microscope (DMi8; Leica Microsystems). The percentage of bone resorption area was measured using ImageJ software version 1.50a (NIH).

\subsection{Western Blotting}

Immunoblotting was performed using primary antibodies against cyclin D3 (BD Biosciences, San Diego, CA, USA), Atg 5, Atg 7, caspase-9, caspase-8, caspase-3, c-Fos, NFATc1, PARP (Cell Signaling Technology), cyclin E1, p21 (GeneTex, Irvine, CA, USA), DC-STAMP (Merck, Kenilworth, NJ, USA), $\beta$-actin, LC3B, and p62 (Proteintech, Chicago, IL, USA). The blots were developed with an enhanced chemiluminescence kit (Amersham Biosciences, Buckinghamshire, UK) and measured using a luminescent image analyzer (LAS-3000; Fuji Photo Film Co., Ltd., Tokyo, Japan) [37].

\subsection{Statistical Analysis}

All data are presented as the mean \pm standard error of the mean. Significant differences between the means of two groups were determined with a $t$-test using GraphPad Prism software version 7.0 (GraphPad Software, San Diego, CA, USA). Statistical significance was considered at $p<0.05$.

\section{Results}

\subsection{4-AAQB Cytotoxicity under Both v-Xg And $\mu \mathrm{Xg}$ Conditions}

Figure 1A shows the chemical structure of 4-AAQB. 4-AAQB and ALN, a positive control, did not alter cell viability in either $\mathrm{v}-\mathrm{Xg}$ or $\mu \mathrm{Xg}$ conditions (Figure 1B). 
A

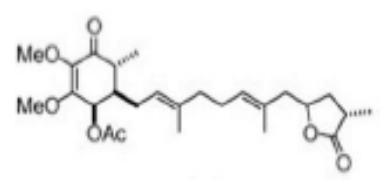

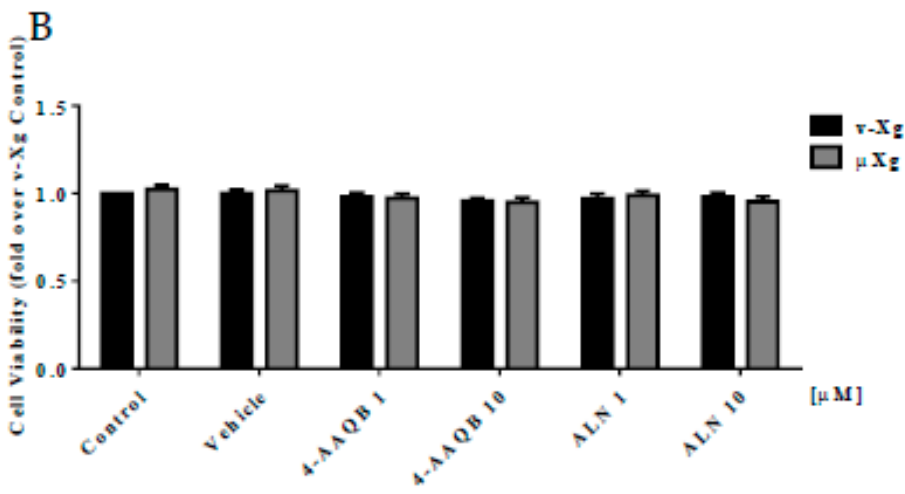

Figure 1. Effects of 4-AAQB on RAW264.7 cell viability. Chemical structure of 4-AAQB (A). Cell viability was assayed by alamarBlue for $2 \mathrm{~h}$ after cell stimulation with $\mathrm{v}-\mathrm{Xg}$ or $\mu \mathrm{Xg}$ for $24 \mathrm{~h}(\mathrm{~B})$. The quantitative results are presented as the mean $\pm \operatorname{SEM}(n=3)$.

3.2. 4-AAQB Effects on RANKL-Induced Osteoclast Formation and Resorption Ability in Both v-Xg and $\mu \mathrm{Xg}$ Conditions

To examine the effects of 4-AAQB on osteoclast formation, TRAP staining was conducted. Our results showed that 4-AAQB eliminated both the number and area of TRAP (+) osteoclasts (Figure 2A-D) under both $v-\mathrm{Xg}$ and $\mu \mathrm{Xg}$ conditions. The number of actin rings was also consistently decreased by 4-AAQB (Figure 2E-G). We further assessed the effects of 4-AAQB on osteoclast resorption activity using an osteo assay. 4-AAQB significantly decreased osteoclast resorption activity as expected (Figure $3 \mathrm{~A}-\mathrm{C}$ ). Based on these findings, 4-AAQB attenuates RANKL-induced osteoclast formation and resorption activity. These findings indicate that $4-\mathrm{AAQB}$ efficiently attenuates osteoclast formation in both $v-\mathrm{Xg}$ and $\mu \mathrm{Xg}$ conditions. Interestingly, 4-AAQB displayed greater efficacy in $\mu \mathrm{Xg}$ than in $\mathrm{v}-\mathrm{Xg}$.

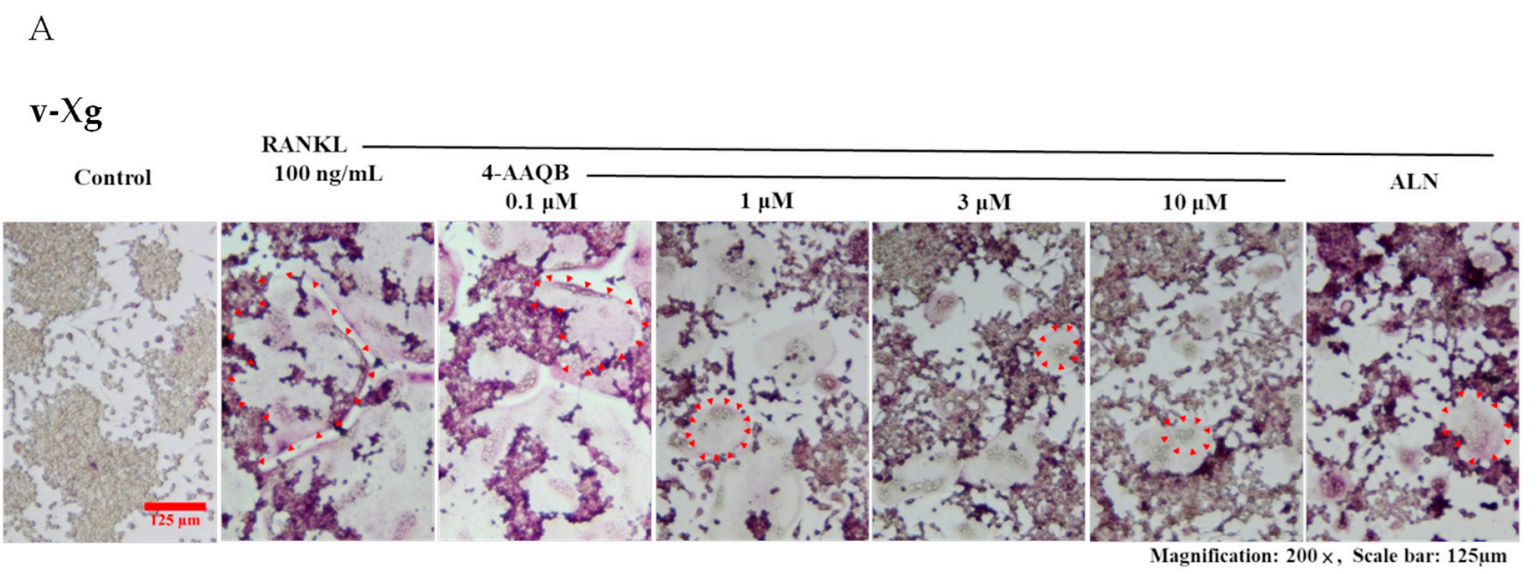

Figure 2. Cont. 
B

$\boldsymbol{\mu X g}$

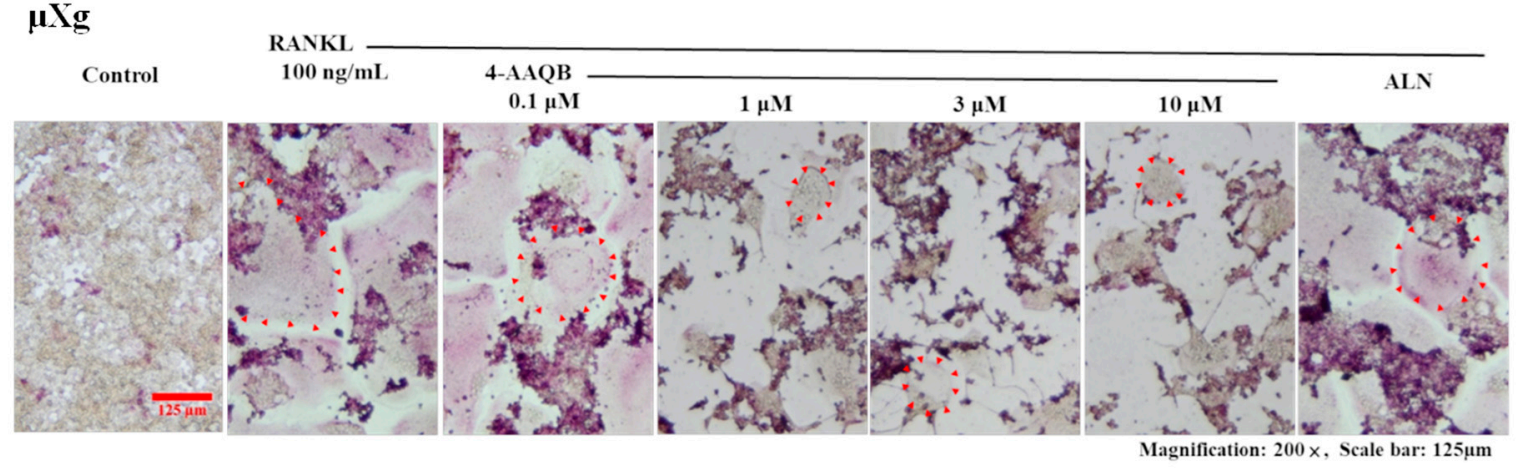

C

D
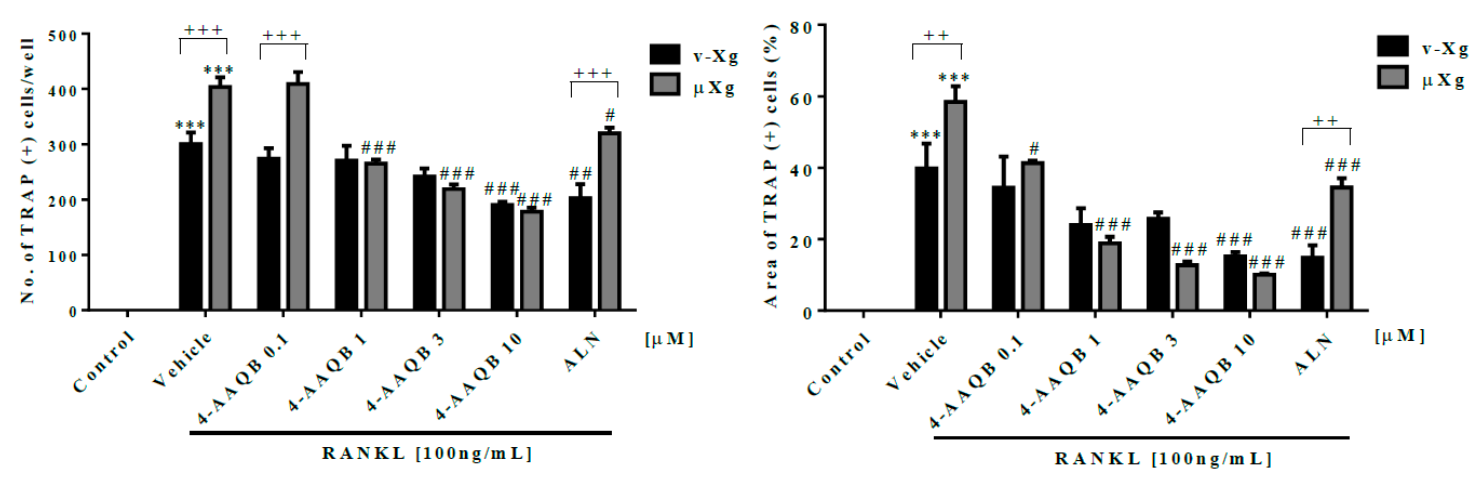

E

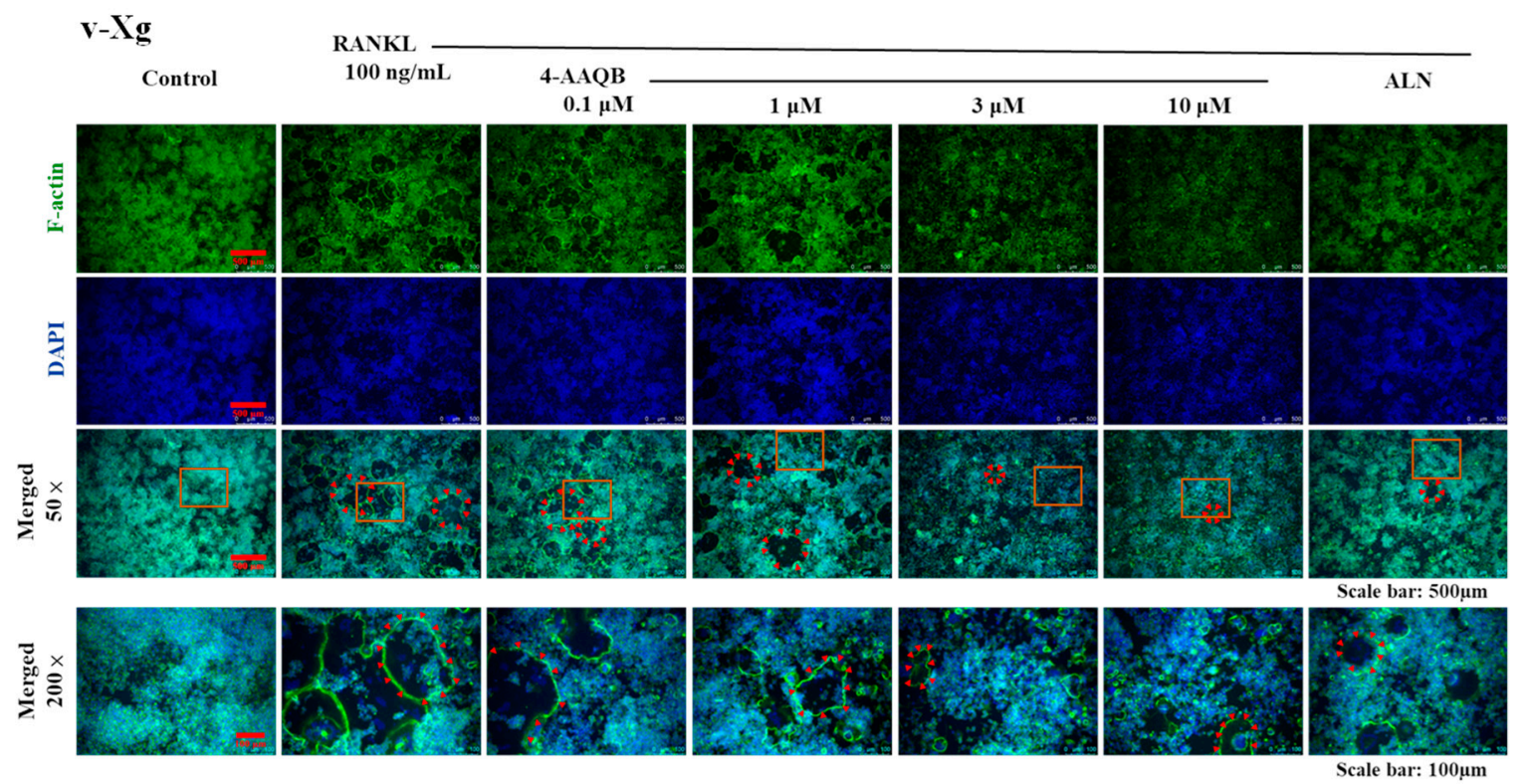

Figure 2. Cont. 


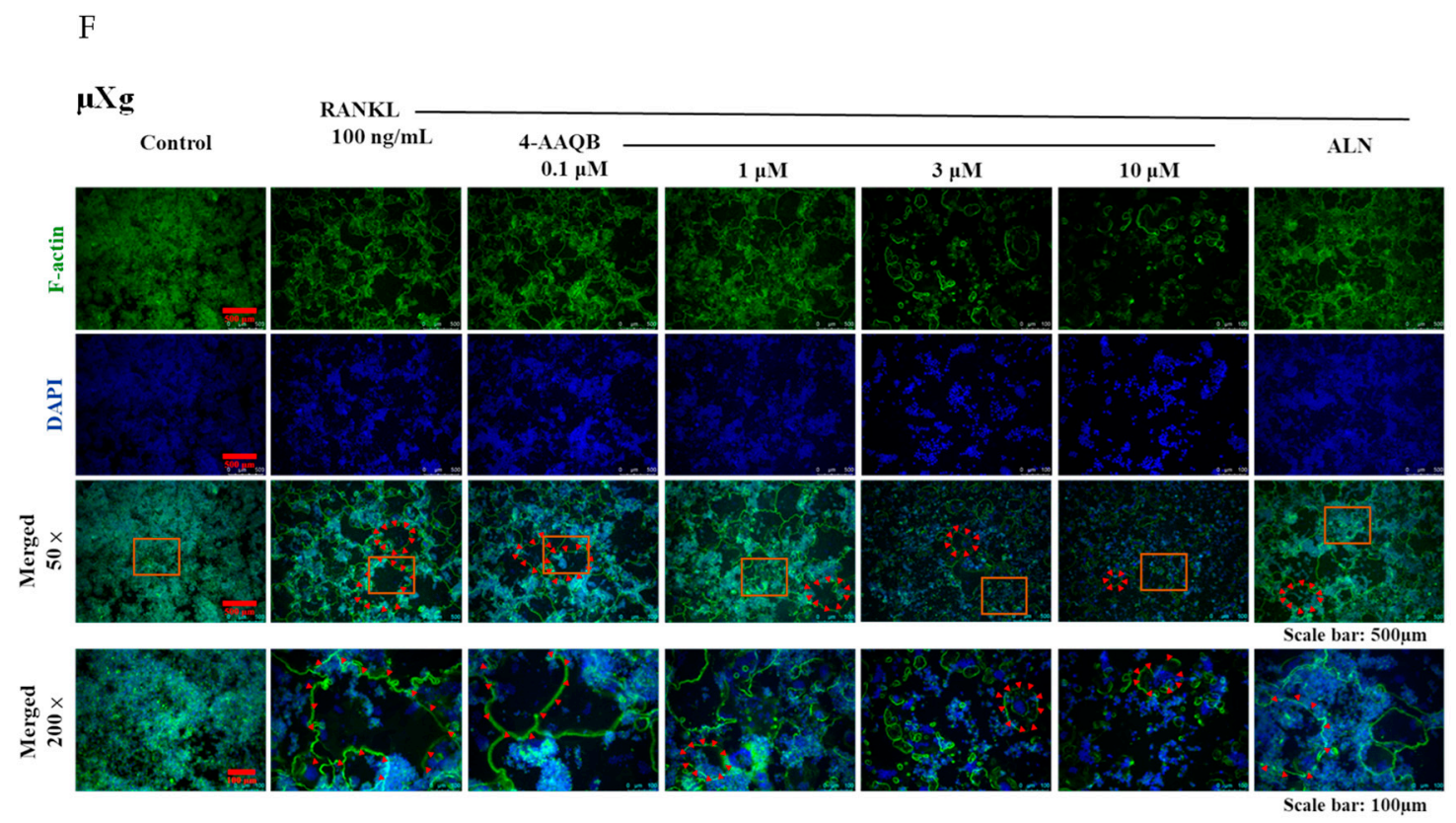

G

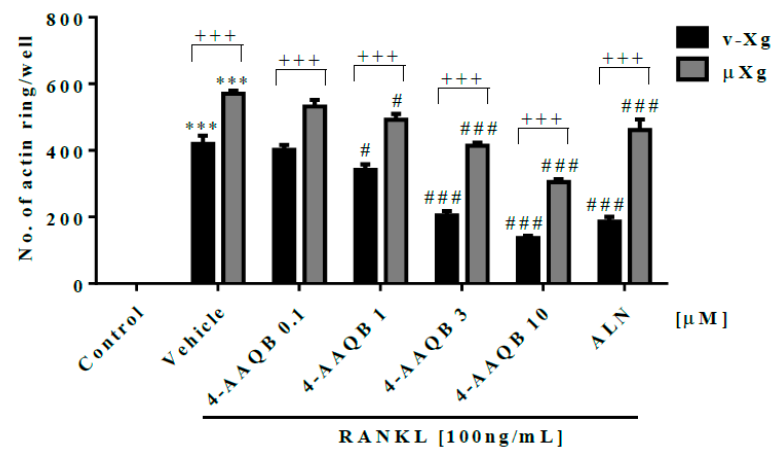

Figure 2. 4-AAQB attenuation of osteoclast formation after $v-X g$ and $\mu \mathrm{Xg}$ stimulation. After exposure in $\mathrm{v}-\mathrm{Xg}(\mathrm{A})$ or $\mu \mathrm{Xg}$ (B) for $24 \mathrm{~h}$, and the cells were treated with 4-AAQB $(0.1,1,3$, or $10 \mu \mathrm{M})$ or ALN $(10 \mu \mathrm{M})$ combined with RANKL for $72 \mathrm{~h}$. The quantitative results of the number of TRAP (+) osteoclasts/well (C) and area of TRAP $(+)$ osteoclasts (\%) (D) represent the mean \pm SEM $(n=6)$. In addition, fluorescent staining (actin ring and DAPI; $(\mathbf{E}, \mathbf{F})$ ) and quantitative results (number of actin rings/well; $(\mathbf{G})$ ) were conducted. Osteoclasts or actin rings are indicated by red arrows. Orange rectangles represent the areas magnified 200 times. ${ }^{* * *} p<0.001$ versus control; $\# p<0.05$, \#\# $p<0.01$, and \#\#\# $p<0.001$ versus RANKL; $++p<0.01$ and $+++p<0.001$ versus $\mathrm{v}-\mathrm{Xg}$. 
A

v-Xg

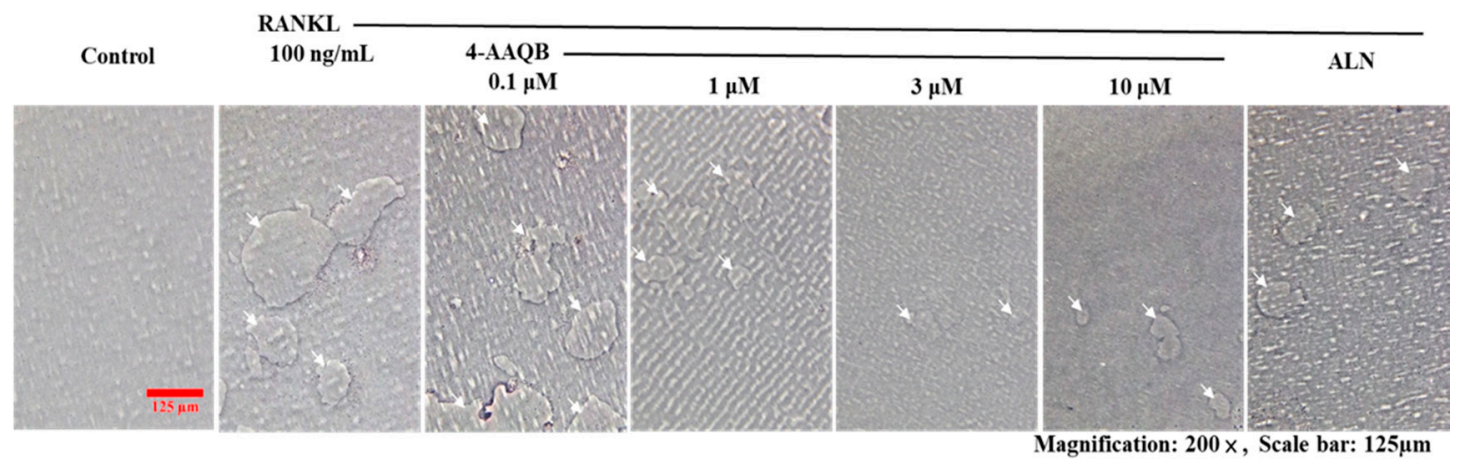

B

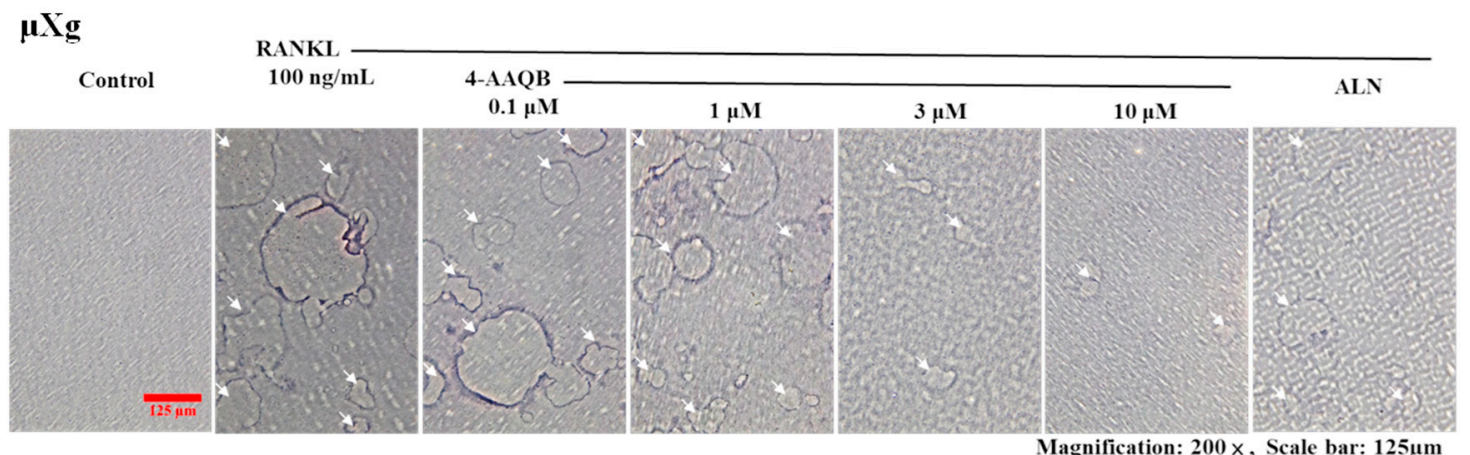

C

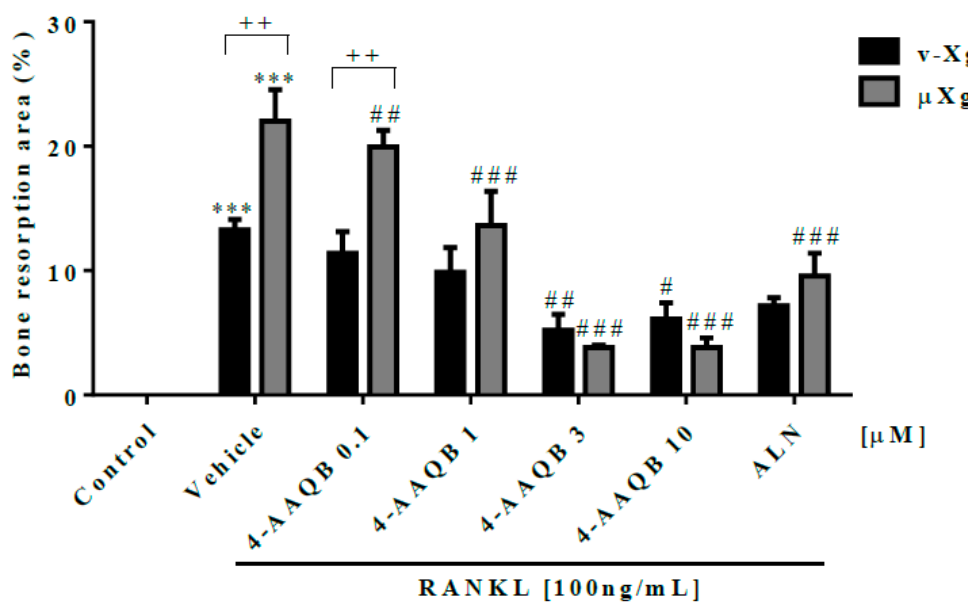

Figure 3. 4-AAQB attenuation of osteoclast resorption ability after $v-X g$ and $\mu \mathrm{Xg}$ stimulation. After exposure in $\mathrm{v}-\mathrm{Xg}(\mathbf{A})$ or $\mu \mathrm{Xg}(\mathbf{B})$ for $24 \mathrm{~h}$, and the cells were cultured in osteo assay 96-well plates and treated with 4 -AAQB $(0.1,1,3$, or $10 \mu \mathrm{M})$ or ALN $(10 \mu \mathrm{M})$ combined with RANKL for $120 \mathrm{~h}$. The bone resorption area $(\%)(C)$ quantitative results represent the mean \pm SEM $(n=4)$. White arrows indicate the resorption pits. ${ }^{* * *} p<0.001$ versus control; \# $p<0.05$, \#\# $p<0.01$, and \#\#\# $p<0.001$ versus RANKL; $++p<0.01$ versus $v-X g$. 


\subsection{Inhibition of Essential Osteoclast Differentiation Pathways by 4-AAQB, Especially in $\mu \mathrm{Xg}$ Conditions}

To confirm the inhibitory effects of 4-AAQB on osteoclastogenesis, the protein levels of c-Fos, NFATc1, and DC-STAMP were analyzed by western blotting. We showed that the NFATc1, c-Fos, and DC-STAMP protein levels were decreased by 4-AAQB in both $v$-Xg (Figure $4 \mathrm{~A}-\mathrm{D}$ ) and $\mu \mathrm{Xg}$ conditions (Figure 4E-H). Thus, 4-AAQB appears to successfully attenuate the osteoclastogenesis signaling pathway, especially under $\mu \mathrm{Xg}$ conditions. In $\mu \mathrm{Xg}$, 4-AAQB not only alleviates osteoclast formation and resorption activities but also suppresses the key regulators of osteoclast differentiation and cell-cell fusion.

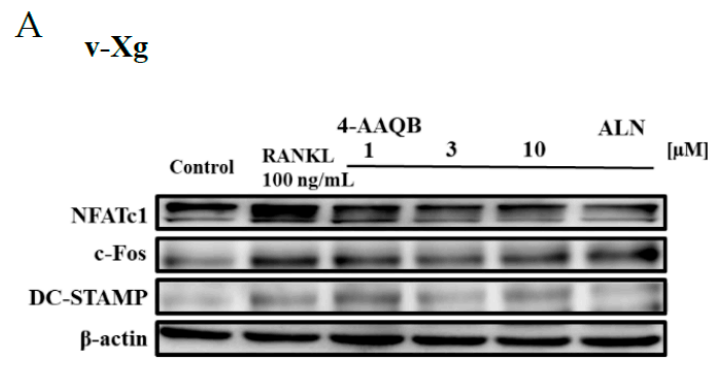

(C)

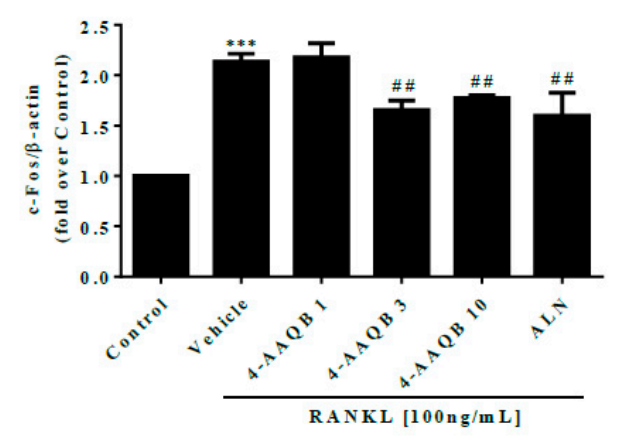

(E)

$\mu \mathrm{Xg}$

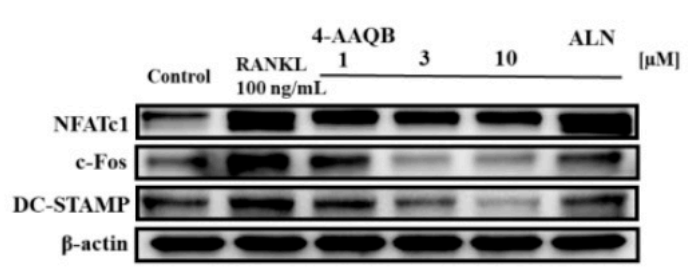

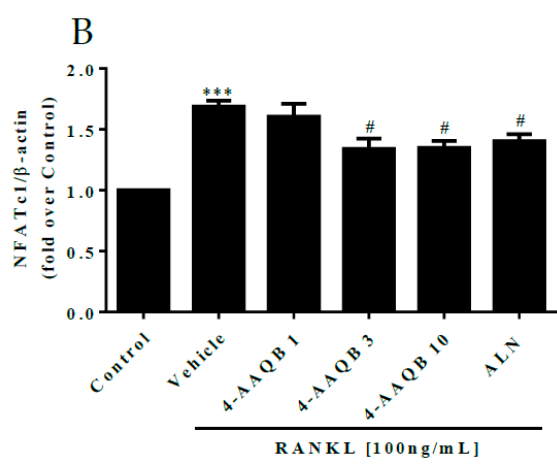

(D)

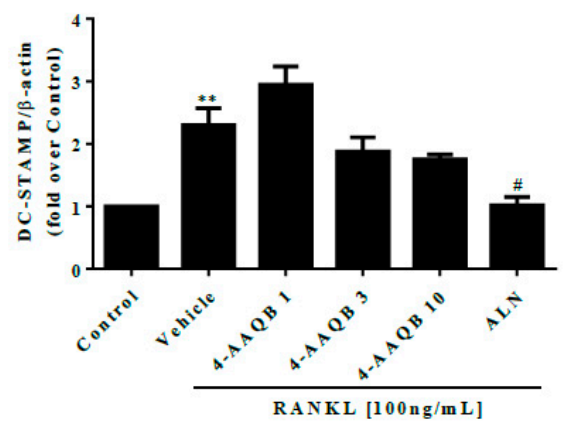

(F)

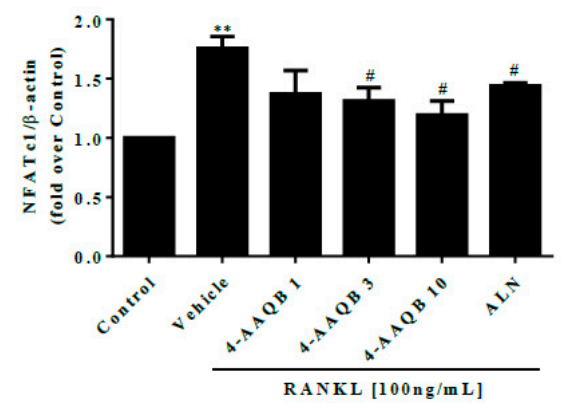

Figure 4. Cont. 
G

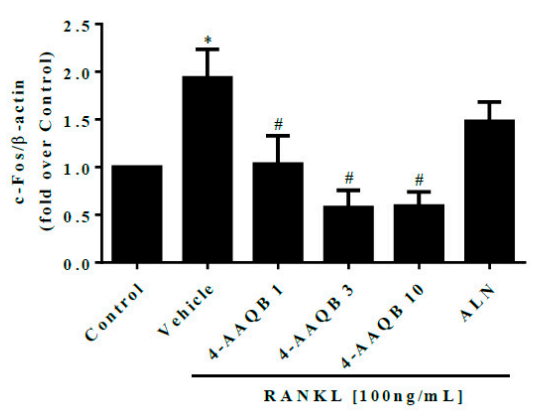

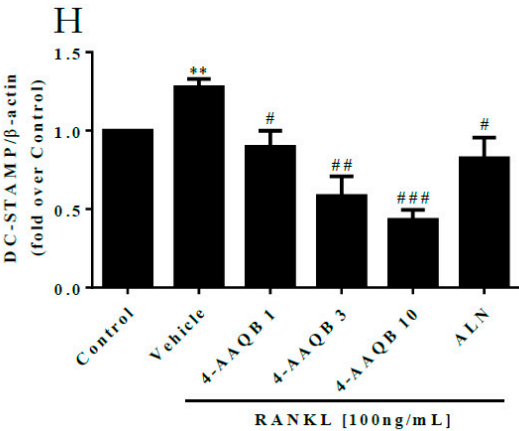

Figure 4. Effects of 4-AAQB on the osteoclastogenesis signaling pathway. Osteoclastogenesis proteins were assayed by western blotting after exposure to $\mathrm{v}-\mathrm{Xg}(\mathrm{A})$ conditions for $24 \mathrm{~h}$. The cells were treated with 4-AAQB $(1,3$, or $10 \mu \mathrm{M})$ or ALN $(10 \mu \mathrm{M})$ combined with RANKL for $54 \mathrm{~h}$. The quantitative results of NFATc1 (B), c-Fos (C), and DC-STAMP (D) represent the mean \pm SEM $(n=3)$. In addition, after exposure to $\mu \mathrm{Xg}(\mathrm{E})$ conditions for $24 \mathrm{~h}$, the cells were treated under the same stimulation conditions as the $\mathrm{v}$-Xg group for $48 \mathrm{~h}$. The quantitative results $(\mathbf{F}-\mathbf{H})$ represent the mean $\pm \operatorname{SEM}(\mathrm{n}=3) .{ }^{*} p<0.05$, ${ }^{* *} p<0.01$ and ${ }^{* * *} p<0.001$ versus control; \# $p<0.05$, \#\# $p<0.01$, and \#\#\# $p<0.001$ versus RANKL.

\subsection{4-AAQB Effects on Osteoclast Apoptosis and Cell Cycle Arrest under $\mu \mathrm{Xg}$ Conditions}

Cell apoptosis and cell cycle-related proteins were further analyzed under $\mu \mathrm{Xg}$ conditions. We found that 4-AAQB increased cleaved caspase-3 and cleaved PARP but decreased cleaved caspase- 8 protein levels (Figure 5A-E). Furthermore, the protein levels of p21, cyclin D3, and cyclin E1 were suppressed by 4-AAQB (Figure 5F-J). These findings indicate that 4-AAQB not only promotes cell apoptosis but also causes cell cycle arrest at the G1-S phase in $\mu \mathrm{Xg}$.

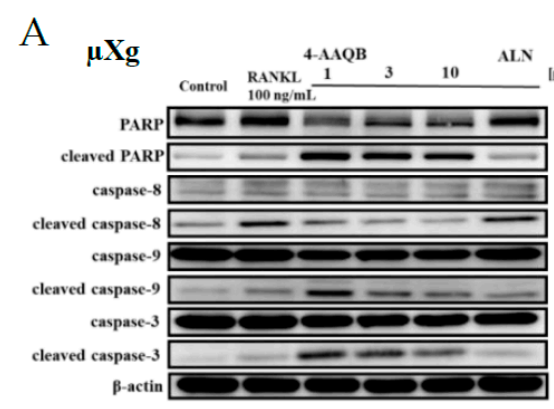

$\mathrm{D}$

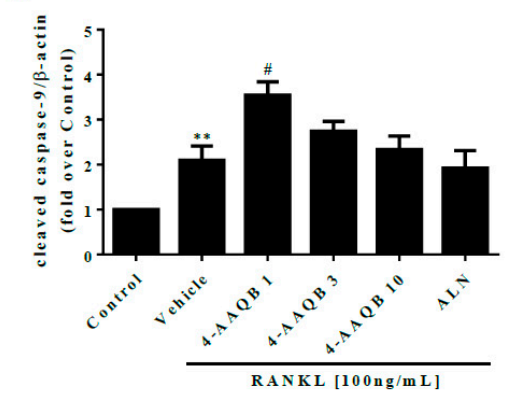

B
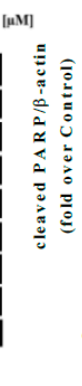

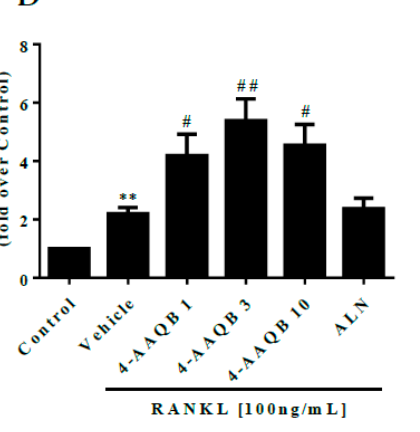

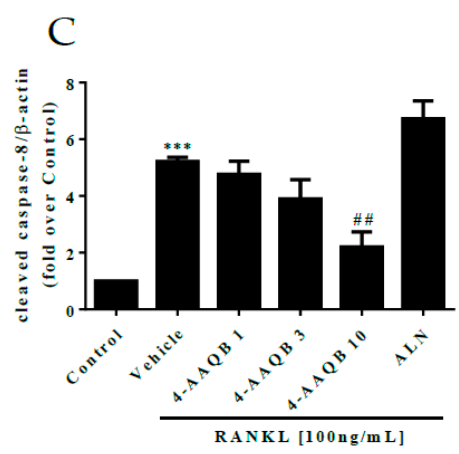

$\mathrm{F}$ $\mu \mathrm{Xg}$

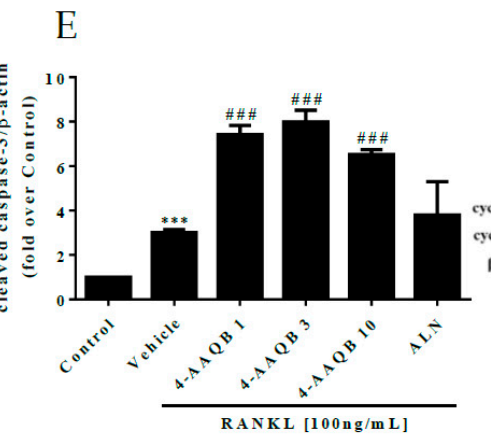

Figure 5. Cont. 

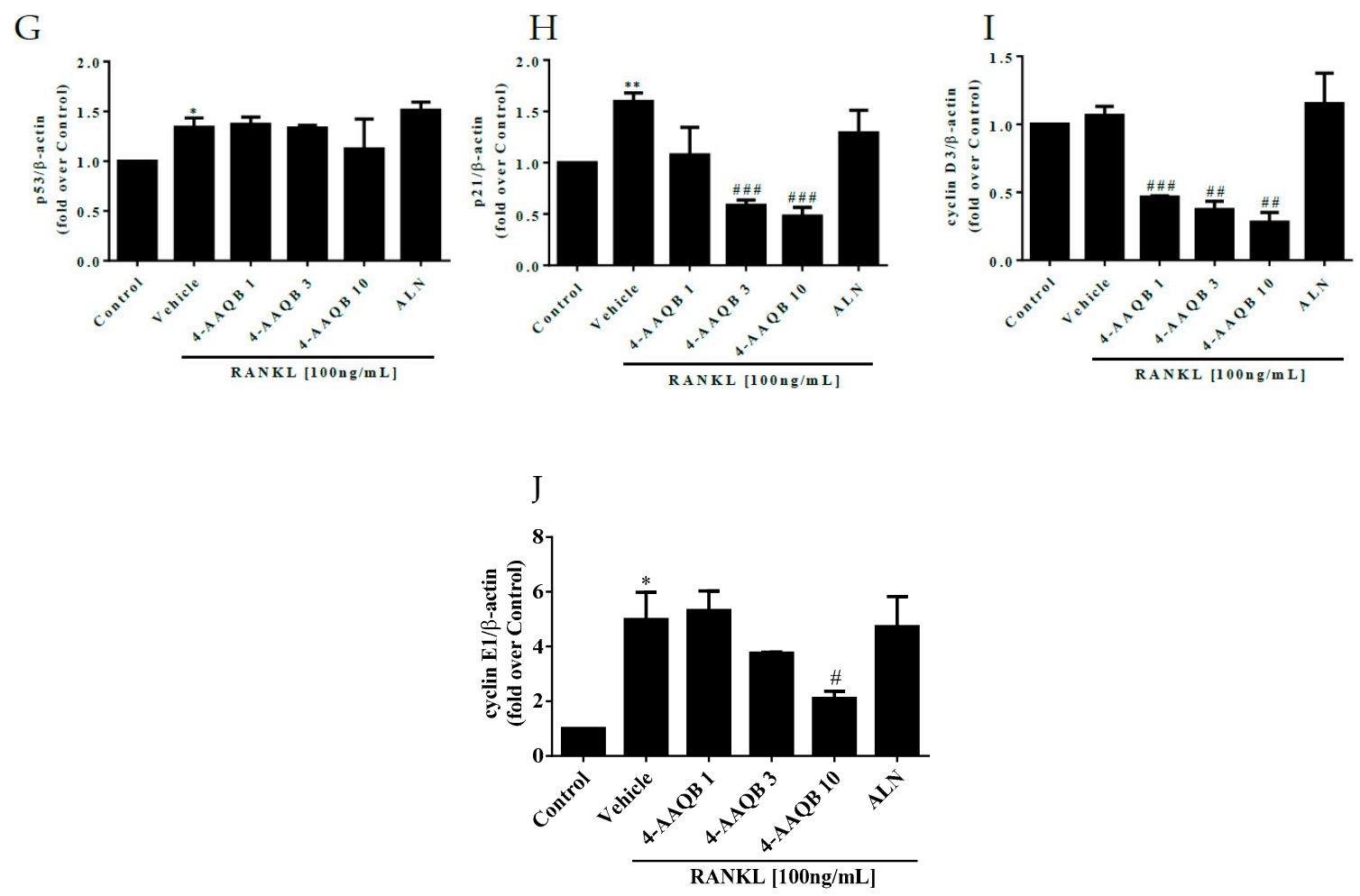

Figure 5. Effects of 4-AAQB on osteoclast apoptosis and the cell cycle after $\mu \mathrm{Xg}$ stimulation. After exposure to $\mu \mathrm{Xg}$ (A) conditions for $24 \mathrm{~h}$, the cells were treated with 4-AAQB or ALN combined with RANKL for $48 \mathrm{~h}$. Apoptotic proteins were assayed by western blotting. The quantitative results of cleaved PARP (B), cleaved caspase-8 (C), cleaved caspase-9 (D), and cleaved caspase-3 (E) represent the mean \pm SEM $(n=3)$. In addition, the cell cycle proteins were also assayed by western blotting $(\mathbf{F})$. The quantitative results of p53 (G), p21 (H), cyclin D3 (I), and cyclin E1 (J) represent the mean \pm SEM $(\mathrm{n}=3) .{ }^{*} p<0.05,{ }^{* *} p<0.01$, and ${ }^{* * *} p<0.001$ versus control; $\# p<0.05$, \#\# $p<0.01$, and \#\#\# $p<0.001$ versus RANKL.

3.5. 4-AAQB Inhibition of RANKL-induced Osteoclastogenesis through an Autophagy-Dependent Pathway Under $\mu \mathrm{Xg}$ Conditions

In addition to cell apoptosis and cell cycle arrest, 4-AAQB significantly decreased the protein levels of LC3B-II/LC3B-I and p62 while minimal change was observed in Atg5 and Atg7 (Figure 6A-E). These findings imply that 4-AAQB regulates osteoclastogenesis through an autophagy-dependent pathway. To confirm this, the autophagy inhibitors 3-MA and chloroquine (CQ) were used in subsequent experiments. The results of TRAP staining (Figure $6 \mathrm{H}-\mathrm{J}$ ) and actin ring immunofluorescence (Figure $6 \mathrm{~K}, \mathrm{~L}$ ) showed that both 3-MA and CQ attenuated osteoclast formation. Both 3-MA and CQ suppressed osteoclastogenesis-related signaling pathway protein markers (Figure $6 \mathrm{M}-\mathrm{P}$ ). These findings indicate that 4-AAQB inhibits $\mu \mathrm{Xg}$-induced osteoclastogenesis through an autophagy-dependent pathway. 
A

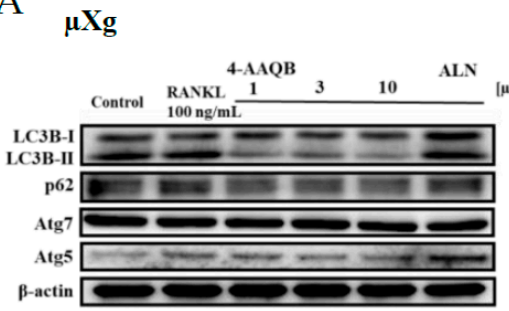

D

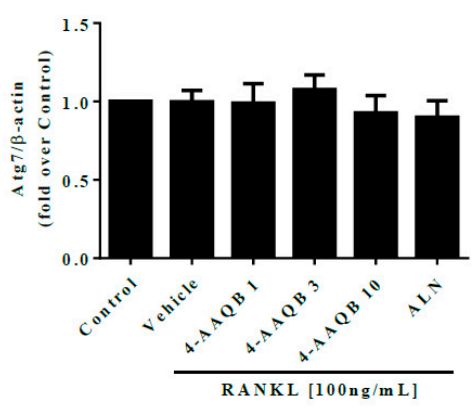

G

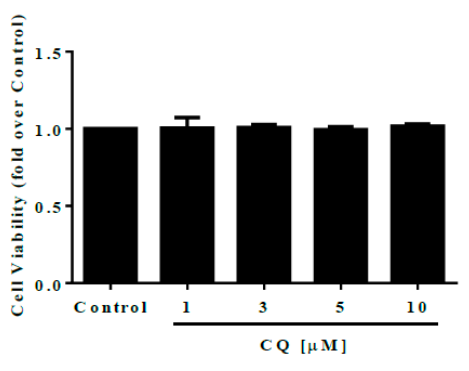

B

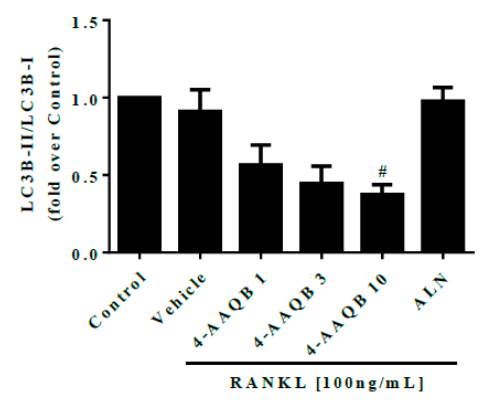

E

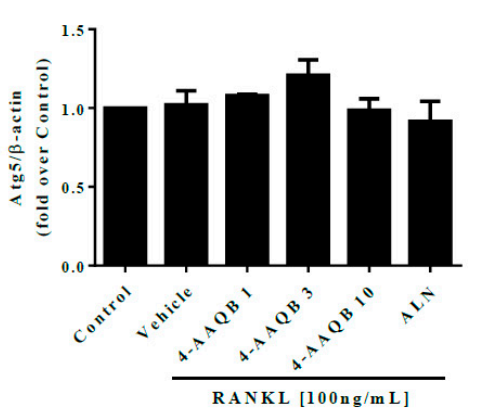

$\mathrm{H}$

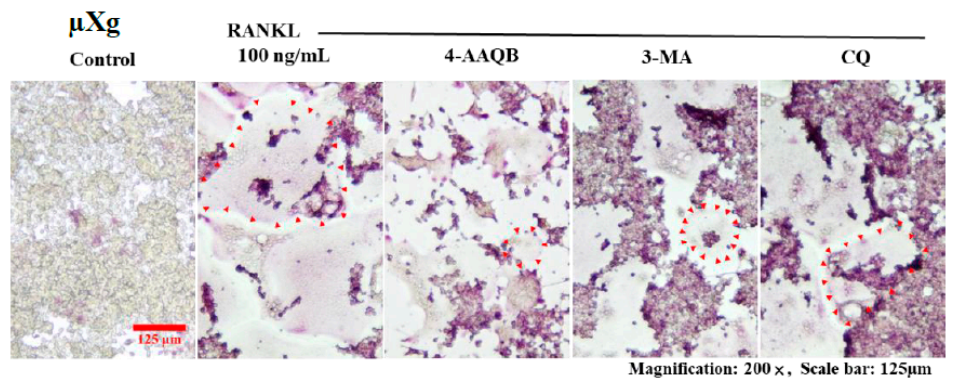

I
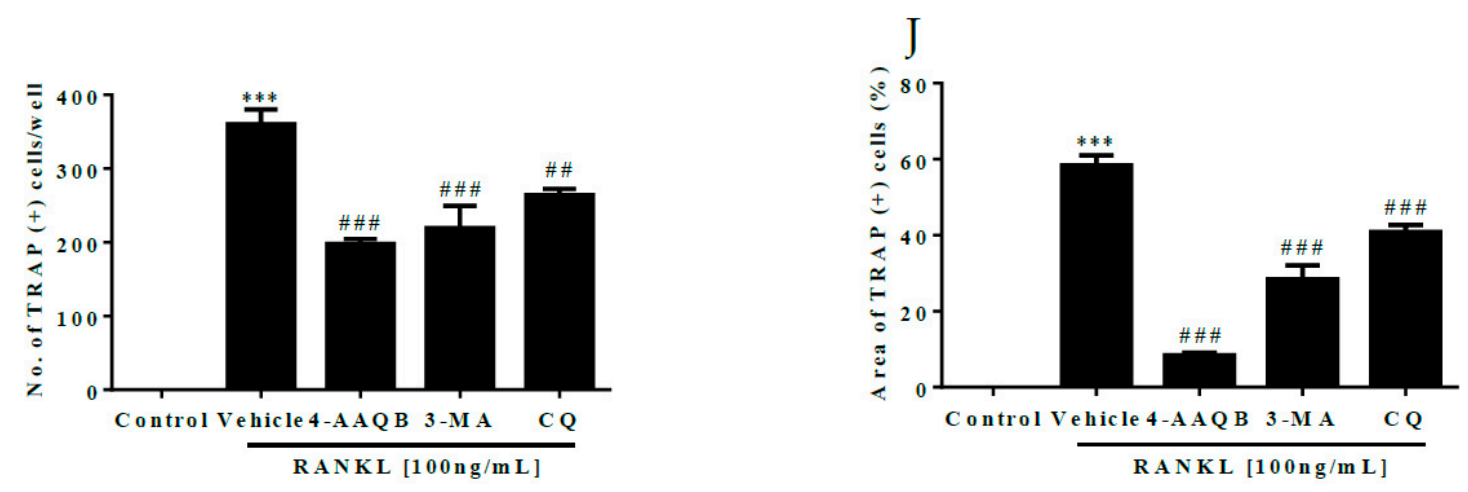

Figure 6. Cont. 


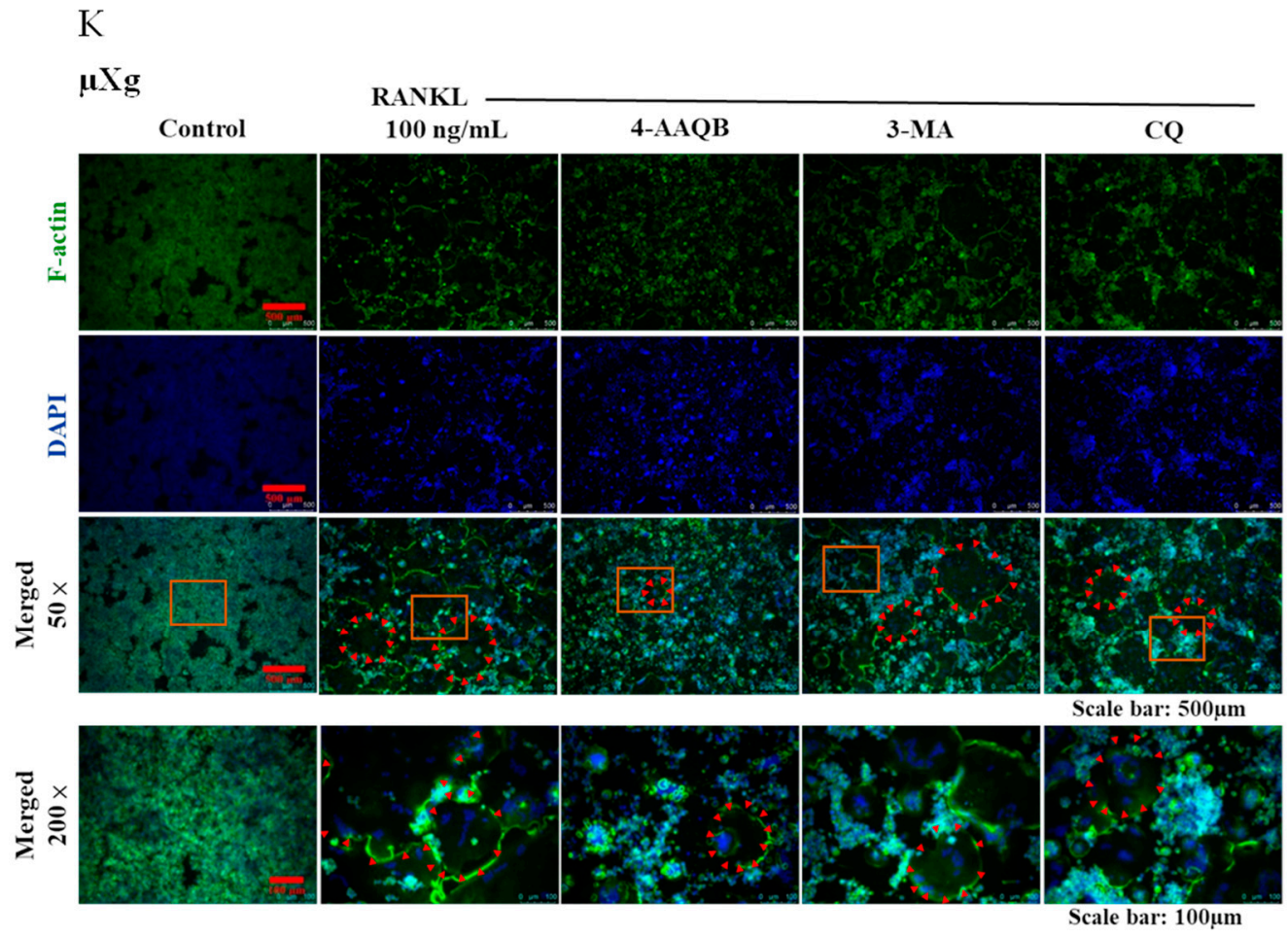

$\mathrm{L}$

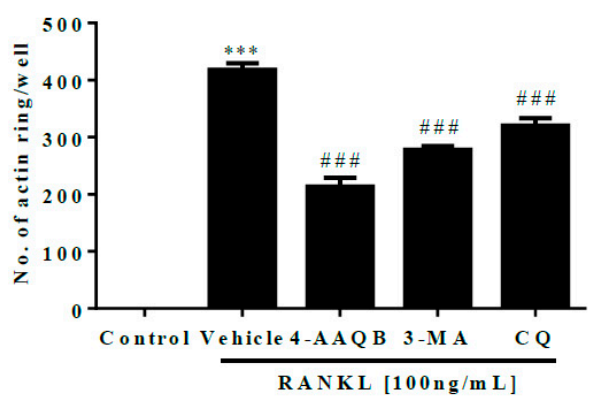

\section{$\mathrm{M}$}

$\mu \mathrm{Xg}$
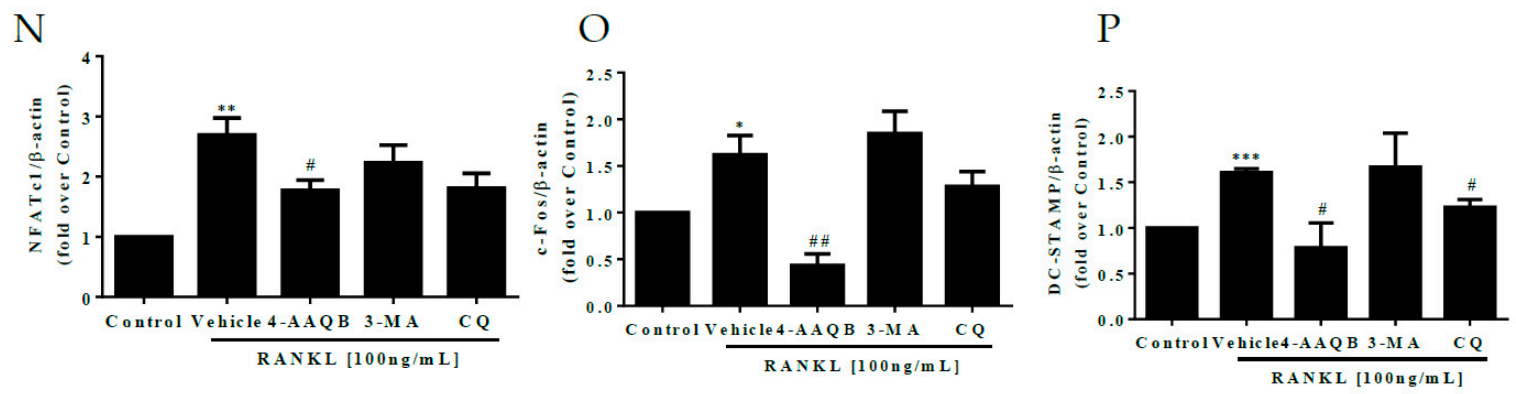

Figure 6. Autophagy inhibitor attenuation of osteoclast formation after $\mu \mathrm{Xg}$ stimulation. Autophagy proteins were assayed by western blotting (A). The quantitative results of LC3B-II/LC3B-I (B), p62 (C), $\operatorname{Atg} 7(\mathbf{D})$, and $\operatorname{Atg} 5($ E) represent the mean $\pm \operatorname{SEM}(n=3)$. Cell viability was assayed by alamarBlue for $2 \mathrm{~h}$ after cell stimulation under $\mu \mathrm{Xg}$ conditions for $24 \mathrm{~h}$; stimulation by 3-MA (F) or CQ (G) continued for $72 \mathrm{~h}$. The quantitative results represent the mean $\pm \operatorname{SEM}(n=3)$. TRAP staining was performed after cell stimulation under $\mu \mathrm{Xg}(\mathbf{H})$ conditions for $24 \mathrm{~h}$. and the cells treated with 4-AAQB $(10 \mu \mathrm{M})$, 
3-MA (1 mM), or CQ $(10 \mu \mathrm{M})$ combined with RANKL for $72 \mathrm{~h}$. The quantitative results of the number of TRAP $(+)$ osteoclasts/well $(\mathbf{I})$ and area of TRAP $(+)$ osteoclasts $(\%)(J)$ represent the mean \pm SEM $(n=6)$. Fluorescent staining was performed after stimulation under $\mu \mathrm{Xg}(\mathbf{K})$ conditions for $24 \mathrm{~h}$, and the cells treated with 4-AAQB, 3-MA, or CQ combined with RANKL for $72 \mathrm{~h}$. The quantitative results of the number of actin rings/well $(\mathbf{L})$ represent the mean \pm SEM $(n=4)$. After exposure to $\mu \mathrm{Xg}(\mathbf{M})$ conditions for $24 \mathrm{~h}$, the cells were treated with 4-AAQB, 3-MA, or CQ combined with RANKL for $48 \mathrm{~h}$. Osteoclastogenesis proteins were assayed by western blotting. The quantitative results of NFATc1 (N), c-Fos $(\mathbf{O})$, and DC-STAMP $(\mathbf{P})$ represent the mean \pm SEM $(n=3)$. Osteoclasts or actin rings are indicated by red arrows. Orange rectangles represent the areas magnified 200 times. ${ }^{*} p<0.05,{ }^{* *} p<0.01$, and *** $p<0.001$ versus control; \# $p<0.05$, \#\# $p<0.01$, and \#\#\# $p<0.001$ versus RANKL.

\section{Discussion}

4-AAQB, a bioactive compound from Antrodia cinnamomea, has shown anti-inflammatory and anti-hepatoma activities [26]. The present study aimed to investigate the inhibitory effects of 4-AAQB on osteoclastogenesis in both $\mathrm{v}-\mathrm{Xg}$ and $\mu \mathrm{Xg}$ conditions. We found that 4-AAQB alleviated osteoclast formation and function in both environments while 4-AAQB exerted a greater protective effect in $\mu \mathrm{Xg}$ than in $\mathrm{v}-\mathrm{Xg}$. We further investigated the mechanistic impact of 4-AAQB under $\mu \mathrm{Xg}$ conditions. 4-AAQB activated osteoclast apoptosis and caused cell cycle arrest accompanied by autophagy suppression (Figure 7). These results suggest that 4-AAQB inhibits osteoclastogenesis by regulating the autophagy pathway.

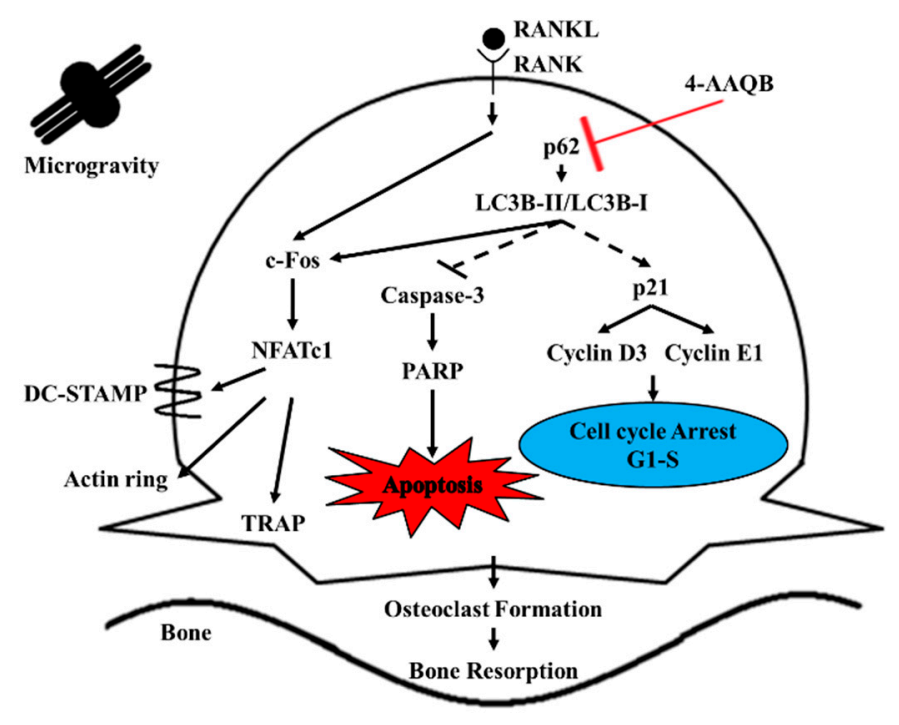

Figure 7. Proposed mechanisms of 4-AAQB in osteoclastogenesis.

Excessive osteoclastogenesis is exhibited in $\mu \mathrm{Xg}$ conditions [38,39]; this is the main reason for $\mu \mathrm{Xg}$-induced bone loss. Our study is the first to investigate the regulatory effects of 4-AAQB on osteoclastogenesis in both $\mathrm{v}-\mathrm{Xg}$ and $\mu \mathrm{Xg}$ conditions. We found that the effects of 4-AAQB in $\mathrm{v}-\mathrm{Xg}$ were similar to those of ALN; however, in $\mu \mathrm{Xg}, 4-\mathrm{AAQB}$ performed more effectively than ALN. Our findings indicate that $4-\mathrm{AAQB}$ exerted a better protective effect than ALN under $\mu \mathrm{Xg}$ conditions, implying a potential role of 4 -AAQB in $\mu \mathrm{Xg}$-induced bone loss. These results provide a basis for exploring the beneficial effects of 4-AAQB in vivo. The chemical structure of 4-AAQB is similar to coenzyme Q10 (CoQ10) [40]. Studies have shown that CoQ10 inhibits osteoclast differentiation by suppressing inflammatory responses, reactive oxygen species generation, and TRAP expression in vitro and in vivo [22,41]. In addition, CoQ10 induces the proliferation and differentiation of osteoblasts [42]. 4-AAQB might show similar mechanisms of action as CoQ10 in osteoblasts. However, this requires further investigation. 
Targeting osteoclast apoptosis is a promising strategy for anti-osteoclastogenesis $[43,44]$. In addition to apoptosis, p21 controls cyclin-dependent kinases [45]. Cyclin D3 and cyclin E regulate the downstream pathways involved in osteoclast differentiation [46]. In our study, we showed that 4-AAQB activated apoptosis and caused cell cycle arrest at the G1-S phase, which is similar to the ALN mechanism $[47,48]$. Based on our findings, we suggest that 4-AAQB attenuates osteoclastogenesis by inducing cell apoptosis and causing cell cycle arrest at the G1-S phase. Interestingly, cell apoptosis is related to the autophagy pathway [32]. $\mu \mathrm{Xg}$ has been reported to induce autophagy in pre-osteoclast RAW264.7 cells [49], which exerts a significant effect on osteoclast differentiation and function [50]. We showed that 4-AAQB suppressed autophagic flux in RANKL-treated cells, which is consistent with the findings of a previous study [27]. In addition, autophagy inhibitors 3-MA and CQ showed similar effects. These findings suggest that $4-\mathrm{AAQB}$ attenuates osteoclast differentiation by suppressing autophagic flux. Autophagy also regulates osteoclast apoptosis [32] and cell cycle in osteoclast progenitors [51]. Combined with the results of apoptosis and cell cycle arrest, we suggest that 4-AAQB attenuates osteoclastogenesis primarily by inhibiting the autophagy pathway. It subsequently activates cell apoptosis and causes cell cycle arrest to alleviate osteoclast differentiation. Furthermore, in previous studies, autophagy was found to regulate cell apoptosis [52] and the cell cycle [53]. These signaling pathways have also been reported to participate in osteoclastogenesis [47,54]. Therefore, we concluded that 4-AAQB inhibits osteoclast differentiation by regulating autophagy to impact cell apoptosis and the cell cycle. Our findings were collected in simulated $\mu \mathrm{Xg}$ conditions, not a real space environment, which is a limitation of this study. However, our results regarding the molecular mechanisms of $4-\mathrm{AAQB}$ may be applied to understanding the space-induced bone loss of astronauts in the future.

\section{Conclusions}

4-AAQB attenuated $\mu \mathrm{Xg}$-induced osteoclastogenesis by suppressing autophagy, inducing apoptosis, and causing cell cycle arrest at the G1-S phase. Thus, we suggest that 4-AAQB may serve as a potential agent against $\mu \mathrm{Xg}$-induced osteoclast formation.

Author Contributions: Conceptualization, C.-H.O. and S.-Y.L.; Data curation, C.-H.W.; Formal analysis, C.-H.O. and C.-H.W.; Funding acquisition, C.-H.O. and S.-Y.L.; Investigation, C.-H.W. and I.-C.Y.; Methodology, I.-C.Y. and C.-H.W.; Resources, C.-H.O.; Supervision, S.-Y.L.; Writing—original draft, C.-H.W. and C.-H.O.; Writing-review \& editing, S.-Y.L. All authors have read and agreed to the published version of the manuscript.

Funding: This work was supported by Grants from the Ministry of Science and Technology (MOST 108-2320-B-016-008-MY3 to S.-Y.L.) and the Cheng Hsin General Hospital (CH-NDMC-108-1 to S.-Y.L.) Taipei, Taiwan.

Acknowledgments: The authors would like to thank the financial support from the Ministry of Science and Technology (MOST 108-2320-B-016-008-MY3 to S.-Y.L.) and the Cheng Hsin General Hospital (CH-NDMC-108-1 to S.-Y.L.) Taipei, Taiwan.

Conflicts of Interest: The authors declare no conflict of interest associated with this manuscript

\section{References}

1. Blaber, E.; Marcal, H.; Burns, B.P. Bioastronautics: The influence of microgravity on astronaut health. Astrobiology 2010, 10, 463-473. [CrossRef] [PubMed]

2. Charles, C.; Christophe, D.; Sandrine, S.; Pierre, M.; Lapiere, C.M.; Betty, M. Gravitational and Space Biology Bulletin; American Society for Gravitational and Space Biology: New Orleans, LA, USA, 2003.

3. Vernikos, J.; Schneider, V.S. Space, gravity and the physiology of aging: Parallel or convergent disciplines? A mini-review. Gerontology 2010, 56, 157-166. [CrossRef] [PubMed]

4. Barger, L.K.; Greenleaf, J.E.; Baldini, F.; Huff, D. Effects of space missions on the human immune system: A meta-analysis. Sports Med. Train. Rehabil. 1995, 5, 293-310. [CrossRef]

5. Dole, N.S. Genetic Determinants of Skeletal Diseases: Role of microRNAs. Ph.D. Thesis, University of Connecticut, Mansfield, CT, USA, 2015. 
6. Lambrecht, G.; Petersen, N.; Weerts, G.; Pruett, C.; Evetts, S.; Stokes, M.; Hides, J. The role of physiotherapy in the European Space Agency strategy for preparation and reconditioning of astronauts before and after long duration space flight. Musculoskelet. Sci. Pract. 2017, 27 (Suppl. 1), S15-S22. [CrossRef]

7. Ontiveros, C.; McCabe, L.R. Simulated microgravity suppresses osteoblast phenotype, Runx2 levels and AP-1 transactivation. J. Cell. Biochem. 2003, 88, 427-437. [CrossRef] [PubMed]

8. Ethiraj, P.; Link, J.R.; Sinkway, J.M.; Brown, G.D.; Parler, W.A.; Reddy, S.V. Microgravity modulation of syncytin-A expression enhance osteoclast formation. J. Cell Biochem. 2018, 119, 5696-5703. [CrossRef]

9. Shanmugarajan, S.; Zhang, Y.; Moreno-Villanueva, M.; Clanton, R.; Rohde, L.H.; Ramesh, G.T.; Sibonga, J.D.; $\mathrm{Wu}, \mathrm{H}$. Combined Effects of Simulated Microgravity and Radiation Exposure on Osteoclast Cell Fusion. Int. J. Mol. Sci. 2017, 18, 2443. [CrossRef]

10. Kim, H.M.; He, L.; Lee, S.; Park, C.; Kim, D.H.; Han, H.J.; Han, J.; Hwang, J.; Cha-Molstad, H.; Lee, K.H.; et al. Inhibition of osteoclasts differentiation by CDC2-induced NFATc1 phosphorylation. Bone 2020, 131, 115153. [CrossRef]

11. Pang, M.; Rodriguez-Gonzalez, M.; Hernandez, M.; Recinos, C.C.; Seldeen, K.L.; Troen, B.R. AP-1 and Mitf interact with NFATc1 to stimulate cathepsin K promoter activity in osteoclast precursors. J. Cell Biochem. 2019, 120, 12382-12392. [CrossRef]

12. Choi, Y.; Yoo, J.H.; Lee, J.H.; Lee, Y.; Bae, M.K.; Kim, Y.D.; Kim, H.J. Connective tissue growth factor (CTGF) regulates the fusion of osteoclast precursors by inhibiting Bcl6 in periodontitis. Int. J. Med. Sci. 2020, 17, 647-656. [CrossRef]

13. Wang, Z.L.; Liu, Y.; Zhou, Y.L.; Li, J.L.; Sun, Q.Y.; Wu, L.X.; Wen, L.; Lai, Y.Y.; Liu, Y.R.; Chang, Y.J.; et al. Osteoclast stimulatory transmembrane protein (OC-STAMP) is a promising molecular prognostic indicator for multiple myeloma. Eur. J. Haematol. 2020, 105, 185-195. [CrossRef] [PubMed]

14. Wada, T.; Nakashima, T.; Hiroshi, N.; Penninger, J.M. RANKL-RANK signaling in osteoclastogenesis and bone disease. Trends Mol. Med. 2006, 12, 17-25. [CrossRef] [PubMed]

15. Bi, H.; Chen, X.; Gao, S.; Yu, X.; Xiao, J.; Zhang, B.; Liu, X.; Dai, M. Key Triggers of Osteoclast-Related Diseases and Available Strategies for Targeted Therapies: A Review. Front. Med. 2017, 4, 234. [CrossRef] [PubMed]

16. Li, H.; Li, C.; Yi, X.; Liu, H.; Wang, Y. Effects of sodium alendronate on osteoporosis and apoptosis-related factors Cyt C, Apaf-1 and caspase-9. Biomed. Res. 2018, 29, 416-420. [CrossRef]

17. Abe, K.; Yoshimura, Y.; Deyama, Y.; Kikuiri, T.; Hasegawa, T.; Tei, K.; Shinoda, H.; Suzuki, K.; Kitagawa, Y. Effects of bisphosphonates on osteoclastogenesis in RAW264.7 cells. Int. J. Mol. Med. 2012, 29, 1007-1015. [PubMed]

18. Xue, Y.; Liang, Z.; Fu, X.; Wang, T.; Xie, Q.; Ke, D. IL-17A modulates osteoclast precursors' apoptosis through autophagy-TRAF3 signaling during osteoclastogenesis. Biochem. Biophys. Res. Commun. 2019, 508, 1088-1092. [CrossRef]

19. Xiu, Y.; Xu, H.; Zhao, C.; Li, J.; Morita, Y.; Yao, Z.; Xing, L.; Boyce, B.F. Chloroquine reduces osteoclastogenesis in murine osteoporosis by preventing TRAF3 degradation. J. Clin. Investig. 2014, 124, 297-310. [CrossRef]

20. Cavanagh, P.R.; Licata, A.A.; Rice, A.J. Exercise And Pharmacological Countermeasures For Bone Loss During Longduration Space Flight. Gravit. Space Biol. 2005, 18, 39-58.

21. LeBlanc, A.; Schneider, V. Countermeasures Against Space Flight Related Bone Loss. Acta Astronaut. 1992, 27,89-92. [CrossRef]

22. Ikegame, M.; Hattori, A.; Tabata, M.J.; Kitamura, K.I.; Tabuchi, Y.; Furusawa, Y.; Maruyama, Y.; Yamamoto, T.; Sekiguchi, T.; Matsuoka, R.; et al. Melatonin is a potential drug for the prevention of bone loss during space flight. J. Pineal Res. 2019, 67, e12594. [CrossRef]

23. Chang, C.H.; Hsu, C.C.; Lee, A.S.; Wang, S.W.; Lin, K.T.; Chang, W.L.; Peng, H.C.; Huang, W.C.; Chung, C.H. 4-Acetylantroquinonol B inhibits lipopolysaccharide-induced cytokine release and alleviates sepsis through of MAPK and NFkappaB suppression. BMC Complement. Altern. Med. 2018, 18, 108. [CrossRef] [PubMed]

24. Li, T.-Y.; Chiang, B.-H. 4-Acetylantroquinonol B from antrodia cinnamomea enhances immune function of dendritic cells against liver cancer stem cells. Biomed. Pharm. 2019, 109, 2262-2269. [CrossRef] [PubMed]

25. Lee, M.T.; Lin, W.C.; Wang, S.Y.; Lin, L.J.; Yu, B.; Lee, T.T. Evaluation of potential antioxidant and anti-inflammatory effects of Antrodia cinnamomea powder and the underlying molecular mechanisms via Nrf2- and NF-kappaB-dominated pathways in broiler chickens. Poult Sci. 2018, 97, 2419-2434. [CrossRef] [PubMed] 
26. Lin, Y.W.; Pan, J.H.; Liu, R.H.; Kuo, Y.H.; Sheen, L.Y.; Chiang, B.H. The 4-acetylantroquinonol B isolated from mycelium of Antrodia cinnamomea inhibits proliferation of hepatoma cells. J. Sci. Food Agric. 2010, 90, 1739-1744. [CrossRef] [PubMed]

27. Liu, M.; Bamodu, O.A.; Huang, W.C.; Zucha, M.A.; Lin, Y.K.; Wu, A.T.H.; Huang, C.C.; Lee, W.H.; Yuan, C.C.; Hsiao, M.; et al. 4-Acetylantroquinonol B suppresses autophagic flux and improves cisplatin sensitivity in highly aggressive epithelial cancer through the PI3K/Akt/mTOR/p70S6K signaling pathway. Toxicol. Appl. Pharm. 2017, 325, 48-60. [CrossRef]

28. Zhu, W.; Yin, Z.; Zhang, Q.; Guo, S.; Shen, Y.; Liu, T.; Liu, B.; Wan, L.; Li, S.; Chen, X.; et al. Proanthocyanidins inhibit osteoclast formation and function by inhibiting the NF-kappaB and JNK signaling pathways during osteoporosis treatment. Biochem. Biophys. Res. Commun. 2019, 509, 294-300. [CrossRef]

29. Yen, I.C.; Lee, S.Y.; Lin, K.T.; Lai, F.Y.; Kuo, M.T.; Chang, W.L. In Vitro Anticancer Activity and Structural Characterization of Ubiquinones from Antrodia cinnamomea Mycelium. Molecules 2017, 22, 747. [CrossRef]

30. Yang, S.S.; Wang, G.J.; Wang, S.Y.; Lin, Y.Y.; Kuo, Y.H.; Lee, T.H. New constituents with iNOS inhibitory activity from mycelium of Antrodia camphorata. Planta Med. 2009, 75, 512-516. [CrossRef]

31. Kim, B.; Lee, K.Y.; Park, B. Icariin abrogates osteoclast formation through the regulation of the RANKL-mediated TRAF6/NF-kappaB/ERK signaling pathway in Raw264.7 cells. Phytomed. Int. J. Phytother. Phytopharm. 2018, 51, 181-190.

32. Kim, C.J.; Shin, S.H.; Kim, B.J.; Kim, C.H.; Kim, J.H.; Kang, H.M.; Park, B.S.; Kim, I.R. The Effects of Kaempferol-Inhibited Autophagy on Osteoclast Formation. Int. J. Mol. Sci. 2018, 19, 125. [CrossRef]

33. Liu, W.H.; Shi, L.S.; Chung, M.C.; Chang, T.C.; Lee, S.Y. Antcamphin M Inhibits TLR4-Mediated Inflammatory Responses by Upregulating the Nrf2/HO-1 Pathway and Suppressing the NLRP3 Inflammasome Pathway in Macrophages. Am. J. Chin. Med. 2019, 47, 1611-1626. [CrossRef] [PubMed]

34. Jia, Y.; Jiang, J.; Lu, X.; Zhang, T.; Zhao, K.; Han, W.; Yang, W.; Qian, Y. Garcinol suppresses RANKL-induced osteoclastogenesis and its underlying mechanism. J. Cell Physiol. 2019, 234, 7498-7509. [CrossRef] [PubMed]

35. Chaugule, S.; Sureshbabu, S.K.; Dakave, S.; Krishna, C.M.; Chaudhari, P.; Indap, M.; Chiplunkar, S. Hexane Fraction of Turbo brunneus Inhibits Intermediates of RANK-RANKL Signaling Pathway and Prevent Ovariectomy Induced Bone Loss. Front. Med. 2019, 10, 608. [CrossRef] [PubMed]

36. Rao, H.; Tan, J.; Faruqi, F.; Beltzer, J. Available online: https://www.corning.com/catalog/cls/documents/ application-notes/snappshots_CLS_AN_144_osteo_assay.pdf (accessed on 22 September 2020).

37. Yen, I.C.; Shi, L.S.; Chung, M.C.; Ahmetaj-Shala, B.; Chang, T.C.; Lee, S.Y. Antrolone, a Novel Benzoid Derived from Antrodia cinnamomea, Inhibits the LPS-Induced Inflammatory Response in RAW264.7 Macrophage Cells by Balancing the NF-[Formula: See text]B and Nrf2 Pathways. Am. J. Chin. Med. 2018, 46, 1297-1313. [CrossRef]

38. Chatani, M.; Mantoku, A.; Takeyama, K.; Abduweli, D.; Sugamori, Y.; Aoki, K.; Ohya, K.; Suzuki, H.; Uchida, S.; Sakimura, T.; et al. Microgravity promotes osteoclast activity in medaka fish reared at the international space station. Sci. Rep. 2015, 5, 14172. [CrossRef]

39. Nabavi, N.; Khandani, A.; Camirand, A.; Harrison, R.E. Effects of microgravity on osteoclast bone resorption and osteoblast cytoskeletal organization and adhesion. Bone 2011, 49, 965-974. [CrossRef]

40. Chou, K.C.; Yang, S.H.; Wu, H.L.; Lin, P.Y.; Chang, T.L.; Sheu, F.; Chen, K.H.; Chiang, B.H. Biosynthesis of Antroquinonol and 4-Acetylantroquinonol B via a Polyketide Pathway Using Orsellinic Acid as a Ring Precursor in Antrodia cinnamomea. J. Agric. Food Chem. 2017, 65, 74-86. [CrossRef]

41. Moon, H.J.; Ko, W.K.; Jung, M.S.; Kim, J.H.; Lee, W.J.; Park, K.S.; Heo, J.K.; Bang, J.B.; Kwon, I.K. Coenzyme q10 regulates osteoclast and osteoblast differentiation. J. Food Sci. 2013, 78, H785-H891. [CrossRef]

42. Zheng, D.; Cui, C.; Yu, M.; Li, X.; Wang, L.; Chen, X.; Lin, Y. Coenzyme Q10 promotes osteoblast proliferation and differentiation and protects against ovariectomy-induced osteoporosis. Mol. Med. Rep. 2018, 17, 400-407. [CrossRef]

43. McCarthy, M. Bones protected by promotion of osteoclast apoptosis. Lancet 1996, 348, 9033. [CrossRef]

44. Liu, W.; Xu, C.; Zhao, H.; Xia, P.; Song, R.; Gu, J.; Liu, X.; Bian, J.; Yuan, Y.; Liu, Z. Osteoprotegerin Induces Apoptosis of Osteoclasts and Osteoclast Precursor Cells via the Fas/Fas Ligand Pathway. PLoS ONE 2015, 10, e0142519. [CrossRef] [PubMed]

45. Harper, J.W.; Elledge, S.J.; Keyomarsi, K.; Dynlacht, B.; Tsai, L.H.; Zhang, P.; Dobrowolski, S.; Bai, C.; Connell-Crowley, L.; Swindell, E. Inhibition of Cyclin-dependent Kinases by p21. Mol. Biol. Cell. 1995, 6, 387-400. [CrossRef] [PubMed] 
46. Bossy, E.; Talmant, M.; Peyrin, F.; Akrout, L.; Cloetens, P.; Laugier, P. An in vitro study of the ultrasonic axial transmission technique at the radius: $1-\mathrm{MHz}$ velocity measurements are sensitive to both mineralization and intracortical porosity. J. Bone Miner. Res. 2004, 19, 1548-1556. [CrossRef] [PubMed]

47. Ding, N.; Liu, C.; Yao, L.; Bai, Y.; Cheng, P.; Li, Z.; Luo, K.; Mei, T.; Li, J.; Xing, J.; et al. Alendronate induces osteoclast precursor apoptosis via peroxisomal dysfunction mediated ER stress. J. Cell Physiol. 2018, 233, 7415-7423. [CrossRef] [PubMed]

48. Kusamori, K.; Katsumi, H.; Abe, M.; Ueda, A.; Sakai, R.; Hayashi, R.; Hirai, Y.; Quan, Y.S.; Kamiyama, F.; Sakane, T.; et al. Development of a novel transdermal patch of alendronate, a nitrogen-containing bisphosphonate, for the treatment of osteoporosis. J. Bone Miner. Res. 2010, 25, 2582-2591. [CrossRef]

49. Ryu, H.W.; Choi, S.H.; Namkoong, S.; Jang, I.S.; Seo, D.H.; Choi, I.; Kim, H.S.; Park, J. Simulated microgravity contributes to autophagy induction by regulating AMP-activated protein kinase. DNA Cell Biol. 2014, 33, 128-135. [CrossRef]

50. Shapiro, I.M.; Layfield, R.; Lotz, M.; Settembre, C.; Whitehouse, C. Boning up on autophagy: The role of autophagy in skeletal biology. Autophagy 2014, 10, 7-19. [CrossRef]

51. Cao, Y.; Zhang, A.; Cai, J.; Yuan, N.; Lin, W.; Liu, S.; Xu, F.; Song, L.; Li, X.; Fang, Y.; et al. Autophagy regulates the cell cycle of murine HSPCs in a nutrient-dependent manner. Exp. Hematol. 2015, 43, $229-242$. [CrossRef] [PubMed]

52. Huang, S.P.; Chien, J.Y.; Tsai, R.K. Ethambutol induces impaired autophagic flux and apoptosis in the rat retina. Dis Model. Mech. 2015, 8, 977-987. [CrossRef]

53. Zheng, K.; He, Z.; Kitazato, K.; Wang, Y. Selective Autophagy Regulates Cell Cycle in Cancer Therapy. Theranostics 2019, 9, 104-125. [CrossRef] [PubMed]

54. Kwon, M.; Kim, J.M.; Lee, K.; Park, S.Y.; Lim, H.S.; Kim, T.; Jeong, D. Synchronized Cell Cycle Arrest Promotes Osteoclast Differentiation. Int J. Mol. Sci. 2016, 17, 1292. [CrossRef] [PubMed]

(C) 2020 by the authors. Licensee MDPI, Basel, Switzerland. This article is an open access article distributed under the terms and conditions of the Creative Commons Attribution (CC BY) license (http://creativecommons.org/licenses/by/4.0/). 